\title{
End Resection at Double-Strand Breaks: Mechanism and Regulation
}

\author{
Lorraine S. Symington \\ Department of Microbiology and Immunology, Columbia University Medical Center, New York, New York 10032 \\ Correspondence: Iss5@columbia.edu
}

RecA/Rad51 catalyzed pairing of homologous DNA strands, initiated by polymerization of the recombinase on single-stranded DNA (ssDNA), is a universal feature of homologous recombination (HR). Generation of ssDNA from a double-strand break (DSB) requires nucleolytic degradation of the $5^{\prime}$-terminated strands to generate $3^{\prime}$-ssDNA tails, a process referred to as $5^{\prime}-3^{\prime}$ end resection. The RecBCD helicase-nuclease complex is the main end-processing machine in Gram-negative bacteria. Mre11-Rad50 and Mre11-Rad50Xrs2/Nbs1 can play a direct role in end resection in archaea and eukaryota, respectively, by removing end-blocking lesions and act indirectly by recruiting the helicases and nucleases responsible for extensive resection. In eukaryotic cells, the initiation of end resection has emerged as a critical regulatory step to differentiate between homology-dependent and endjoining repair of DSBs.

$\mathrm{D}$ SBs can arise accidentally during normal cell metabolism or after exposure of cells to DNA-damaging agents, and also serve as intermediates in a number of programmed recombination events in eukaryotic cells (Mehta and Haber 2014). The repair of DSBs is critical for maintenance of genome integrity, and misrepair, or failure to repair, is associated with chromosome rearrangements, chromosome loss, or even cell death. Both prokaryotic and eukaryotic cells have evolved elaborate mechanisms for the recognition and repair of DSBs. The two predominant repair mechanisms are HR and nonhomologous end joining (NHEJ). HR relies on the presence of an intact homologous duplex to template repair of the broken strands, whereas NHEJ repairs DSBs by direct ligation of the DNA ends. For DSBs to be repaired by HR, the ends must first be degraded to generate long $3^{\prime}$ ssDNA tails, a process referred to as $5^{\prime}-3^{\prime}$ end resection. The $3^{\prime}$-ssDNA tails are then bound by a member of the RecA/Rad51 family of proteins to initiate homologous pairing and serve as primers for DNA synthesis following strand invasion. Strand invasion intermediates are further processed by helicases and/or nucleases (Bizard and Hickson 2014; Wyatt and West 2014), and ultimately by gap-filling DNA synthesis and ligation, to generate mature recombinant products. The DNA end-resection step of $\mathrm{HR}$ is conserved in all domains of life, but the mechanisms used for generating ssDNA are distinct. Here, we review the basic machinery for DNA end resection in bacteria, archaea, and eukaryota and the regulation of end resection in eukaryotic cells.

Editors: Stephen Kowalczykowski, Neil Hunter, and Wolf-Dietrich Heyer

Additional Perspectives on DNA Recombination available at www.cshperspectives.org

Copyright (C) 2014 Cold Spring Harbor Laboratory Press; all rights reserved; doi: 10.1101/cshperspect.a016436

Cite this article as Cold Spring Harb Perspect Biol 2014;6:a016436 
L.S. Symington

\section{END RESECTION IN BACTERIA}

The heterotrimeric RecBCD nuclease is the major end-processing machine in Escherichia coli and is conserved across the majority of Gramnegative bacteria (Dillingham and Kowalczykowski 2008). RecBCD is a complex enzyme that couples ATP-dependent unwinding to DNA degradation (Smith 2001; Dillingham and Kowalczykowski 2008). The potent exonuclease activity of RecBCD can degrade thousands of bases per second. This destructive activity of RecBCD plays an important role in protecting bacteria from invading bacteriophages with linear genomes. Nuclease activity resides in the carboxy-terminal region of the $\mathrm{RecB}$ subunit and is regulated by $\mathrm{RecC}$ and by interaction with a specific sequence called Chi (5'GCTGGTGG-3') (Wang et al. 2000). Chi sites suppress the nuclease activity of RecBCD and stimulate recombination locally (Lam et al. 1974; Dixon and Kowalczykowski 1993). The 8-bp nonpalindromic Chi sites are overrepresented in the E. coli genome and are oriented toward the replication origin such that loading of RecBCD at a collapsed replication fork would lead to suppression of DNA degradation upon Chi recognition by $\mathrm{RecBCD}$ and activation of HR (Blattner et al. 1997).

Our current view of how RecBCD promotes recombination derives from a combination of bulk-phase biochemistry, single-DNA molecule imaging, electron microscopy (EM), and structural studies. RecBCD binds with high affinity to blunt or nearly blunt-ended linear duplex DNA (Taylor and Smith 1985). Unwinding is driven by the RecB and RecD subunits, which are helicases with opposite polarities and thus translocate the complex on both strands of duplex DNA in the same direction (Dillingham et al. 2003; Taylor and Smith 2003). The robust translocase activity of the RecBCD complex is able to displace tightly bound proteins from duplex DNA (Finkelstein et al. 2010). Under conditions in which the nuclease activity of the complex is minimized, the enzyme unwinds duplex DNA to produce one long $5^{\prime}$-ssDNA tail and an ssDNA loop associated with a short $3^{\prime}$-ssDNA tail owing to the two helicases operating at different speeds
(Taylor and Smith 2003). RecD is the fast, or lead, motor on the $5^{\prime}$-terminated strand, whereas RecB translocates more slowly on the $3^{\prime}$-terminated strand until the complex encounters a Chi site (Fig. 1). Upon Chi recognition, the enzyme pauses, the RecD subunit is inactivated, and continued unwinding is driven by the RecB helicase, resulting in a slower translocation rate (Spies et al. 2003). Before encountering Chi, the $3^{\prime}$ end is more extensively cleaved by the RecB endonuclease than the 5-terminated strand, but after Chi recognition, degradation of the $3^{\prime}$ end is suppressed, and cleavage of the $5^{\prime}$-terminated strand is stimulated, generating a $3^{\prime}$-ssDNA tail (Anderson and Kowalczykowski 1997a). In addition, RecB facilitates loading of RecA onto the 3 '-terminated strand after Chi recognition (Anderson and Kowalczykowski 1997b). How does Chi regulate the nuclease activities of the RecBCD complex? Structural studies indicate that a "pin" in RecC separates the strands of duplex DNA entering the complex driven by the RecB and RecD translocases (Singleton et al. 2004). As the separated strands pass through the RecBCD complex, the RecC subunit recognizes Chi, resulting in a conformational change that opens a molecular latch allowing the $3^{\prime}$-terminated strand to bypass the RecB nuclease domain and exit the complex (Handa et al. 2012; Yang et al. 2012).

The RecBC enzyme behaves similarly to Chi-modified RecBCD. RecBC unwinds double-stranded DNA (dsDNA) more slowly than RecBCD and constitutively loads RecA onto the $3^{\prime}$ end of the unwound strands. Consistent with the in vitro studies, $r e c D$ mutants are recombination proficient and recombination is stimulated at ends instead of in the vicinity of Chi sites (Thaler et al. 1989; Churchill et al. 1999). By contrast, $\operatorname{rec} B$ and $\operatorname{rec} C$ mutants show high sensitivity to $\mathrm{X}$ rays and low frequency of recombination as measured by conjugation or transduction (Persky and Lovett 2008). However, these defects can be suppressed by inactivation of the $3^{\prime}$ exonucleases ExoI and SbcCD, suggesting that an alternative mechanism is able to generate $3^{\prime}$-ssDNA tailed intermediates in the absence of RecBCD, but the ends are unstable because of $3^{\prime}$ nuclease activity. Recombination in the rec $B C$-suppressed strains is caused by the 
Processing of DNA Breaks: Mechanism and Regulation

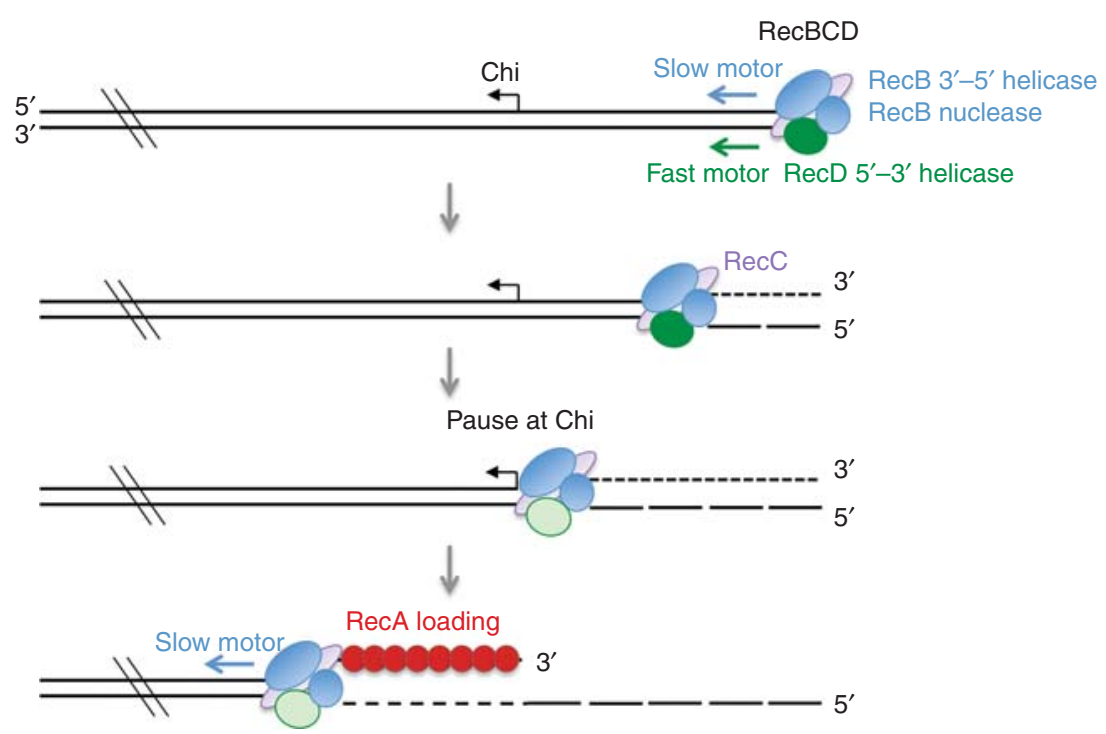

Figure 1. End processing by the RecBCD complex. RecBCD loads at ends and translocates on both strands using the RecD and RecB helicase subunits. RecB degrades both DNA strands exiting the complex, but with more incisions on the $3^{\prime}$ strand than the $5^{\prime}$-terminated strand. RecBCD pauses at a Chi site, and the RecD subunit is modified; continued translocation is driven by the RecB helicase. After Chi recognition, RecB directs loading of RecA onto the $3^{\prime}$ end and degrades only the $5^{\prime}$ strand.

RecF pathway of recombination, which normally functions during ssDNA gap repair (Persky and Lovett 2008). Resection by the RecF pathway requires the $5^{\prime}-3^{\prime}$ exonuclease, RecJ, and is stimulated by the RecQ $3^{\prime}-5^{\prime}$ helicase and the ssDNA-binding protein, SSB (Han et al. 2006; Handa et al. 2009). RecJ requires an ssDNA tail of $>6$ nucleotides for binding and degrades to the ssDNA-dsDNA junction, releasing mononucleotide products (Han et al. 2006). Although originally characterized biochemically as an ssDNA-specific exonuclease, RecJ shows limited degradation of dsDNA (Lovett and Kolodner 1989; Handa et al. 2009). In a reconstituted reaction with other RecF pathway proteins, RecJ was shown to generate sufficient ssDNA to promote RecA-catalyzed strand invasion, although the extent of degradation and joint molecule formation was less than observed in the presence of RecQ (Handa et al. 2009).

The normal function of the RecF pathway is to promote recombination at ssDNA gaps formed during replication - for example, when a UV-induced pyrimidine dimer prevents primer extension by DNA polymerase III (see Syeda et al.
2014). recJ and recQ mutants show UV sensitivity and may be required to expand ssDNA gaps to facilitate RecA binding (Persky and Lovett 2008). RecJ can also cooperate with RecB and RecC in the absence of RecD (Lovett et al. 1988; Dermic 2006). The high frequency of conjugal recombination observed in recD mutants is reduced by mutation of recJ, but not by recQ. The residual recombination observed in the recD recJ mutant requires ExoVII, which degrades ssDNA from $5^{\prime}$ or $3^{\prime}$ ends, but the recD xseA mutant is recombination proficient, indicating that RecJ is the main activity with ExoVII serving as a backup function (Dermic 2006).

Ironically, there appears to be no role for $\mathrm{SbcCD}$ in end resection in bacteria, in contrast to archaea and eukaryota, where the $\mathrm{SbcC}$ and $\mathrm{SbcD}$ orthologs, Rad50 and Mre11, respectively, play an important role in coordinating DNA end processing (see below). Instead, the main function of SbcCD is to resolve hairpin structures formed by annealing between closely spaced inverted repeats, a role that is conserved in yeast (Lobachev et al. 2002; Rattray et al. 2005; Eykelenboom et al. 2008). 
L.S. Symington

\section{END RESECTION IN ARCHAEA}

Homologs of the helicases and nucleases responsible for end resection in bacteria have not been identified in any of the archaeal genomes examined to date; RecQ-like helicases have been found but have no characterized role in end resection (Guy and Bolt 2005; Fujikane et al. 2006; Oyama et al. 2009). Mrel1 and Rad50 are present in archaea, and biochemical studies suggest a role in end processing. Most of the structural analyses have been performed with the archaeal proteins; however, the functional analysis of catalytic and architectural motifs has mainly been performed in yeast (see below). Mre11 shows $\mathrm{Mn}^{2+}$-dependent $3^{\prime}-5^{\prime}$ exonuclease activity in vitro and an endonuclease activity that acts at the dsDNA-ssDNA transition of secondary structures within ssDNA (Hopfner et al. 2000a; Trujillo and Sung 2001). The genes encoding Mre11 and Rad50 are within the same operon as the HerA helicase and the NurA nuclease in thermophilic archaea, suggesting they might functionally cooperate to promote end resection (Hopkins and Paull 2008). HerA is a member of the FtsK superfamily of hexameric translocases and helicases, and NurA forms a dimer with RNaseH-like domains (Blackwood et al. 2012). HerA and NurA physically interact, and the catalytic activities are mutually interdependent (Hopkins and Paull 2008; Blackwood et al. 2012). In assays with limiting amounts of HerA and NurA, addition of Mre11 and Rad50 strongly stimulates ATP-dependent DNA degradation, requiring the helicase and nuclease activities of HerA and NurA, respectively (Hopkins and Paull 2008). Interestingly, the Mre11Rad50 (MR) complex alone is able to remove 15-55 nt from the $5^{\prime}$ ends of long linear substrates in a reaction dependent on the Mre11 nuclease and $\mathrm{Mg}^{2+}$. The initial processing by MR stimulates degradation by NurA but is not essential for end resection in the reconstituted reaction (Hopkins and Paull 2008).

\section{END RESECTION IN EUKARYOTES}

Much of our knowledge of the factors involved in eukaryotic end resection has come from ge- netic analysis in Saccharomyces cerevisiae, where DNA end processing can be followed physically at sites of endonuclease-generated DSBs in vegetatively dividing (mitotic) cells or Spol1-induced DSBs in meiosis. These studies identified the Mre11-Rad50-Xrs2 (MRX) complex, Sae2, Exo1, Replication Protein A (RPA), Sgs1, and Dna2 as key factors for $5^{\prime}-3^{\prime}$ end resection, and their activities are conserved in other eukaryotes investigated (human NBS1, CtIP, and BLM are the functional orthologs of Xrs2, Sae2, and Sgs1, respectively) (Gravel et al. 2008; Mimitou and Symington 2008; Zhu et al. 2008; Nimonkar et al. 2011; Peterson et al. 2011; Karanja et al. 2012; Chen et al. 2013). A widely accepted view is for MRX/N and Sae2/CtIP to initiate end resection by endonucleolytic cleavage of the $5^{\prime}$ ends internal to break ends releasing oligonucleotides. The short $3^{\prime}$-ssDNA tails formed are then subject to extensive resection executed via two parallel pathways. One is dependent on the $5^{\prime}-3^{\prime}$ exonuclease, Exo1, whereas the other depends on the concerted action of the Sgs1/ BLM-Top3-Rmi1 complex with the Dna2 endonuclease, hereafter referred to as STR-Dna2. The extensively resected ssDNA tracts formed vary in length from a few hundred nucleotides to tens of kilobases, depending on the availability and location of the homologous template, and correlate with the kinetics of repair (Chung et al. 2010).

Biochemical and Structural Characterization of Resection Nucleases

\section{$M R X / N$}

The MRE11, RAD50, and XRS2 genes were originally identified by their essential roles for ionizing radiation (IR) resistance and meiotic recombination, and null mutations confer similar phenotypes (Mimitou and Symington 2009). Mre11, Rad50, and Xrs2/Nbs1 interact and copurify as a complex (Trujillo et al. 1998; Usui et al. 1998; Paull and Gellert 1999). Mre11 has five conserved phosphoesterase motifs in the amino-terminal half of the protein that are required for $\mathrm{Mn}^{2+}$-dependent $3^{\prime}-5^{\prime}$ dsDNA exonuclease and ssDNA endonuclease activities in 
Processing of DNA Breaks: Mechanism and Regulation
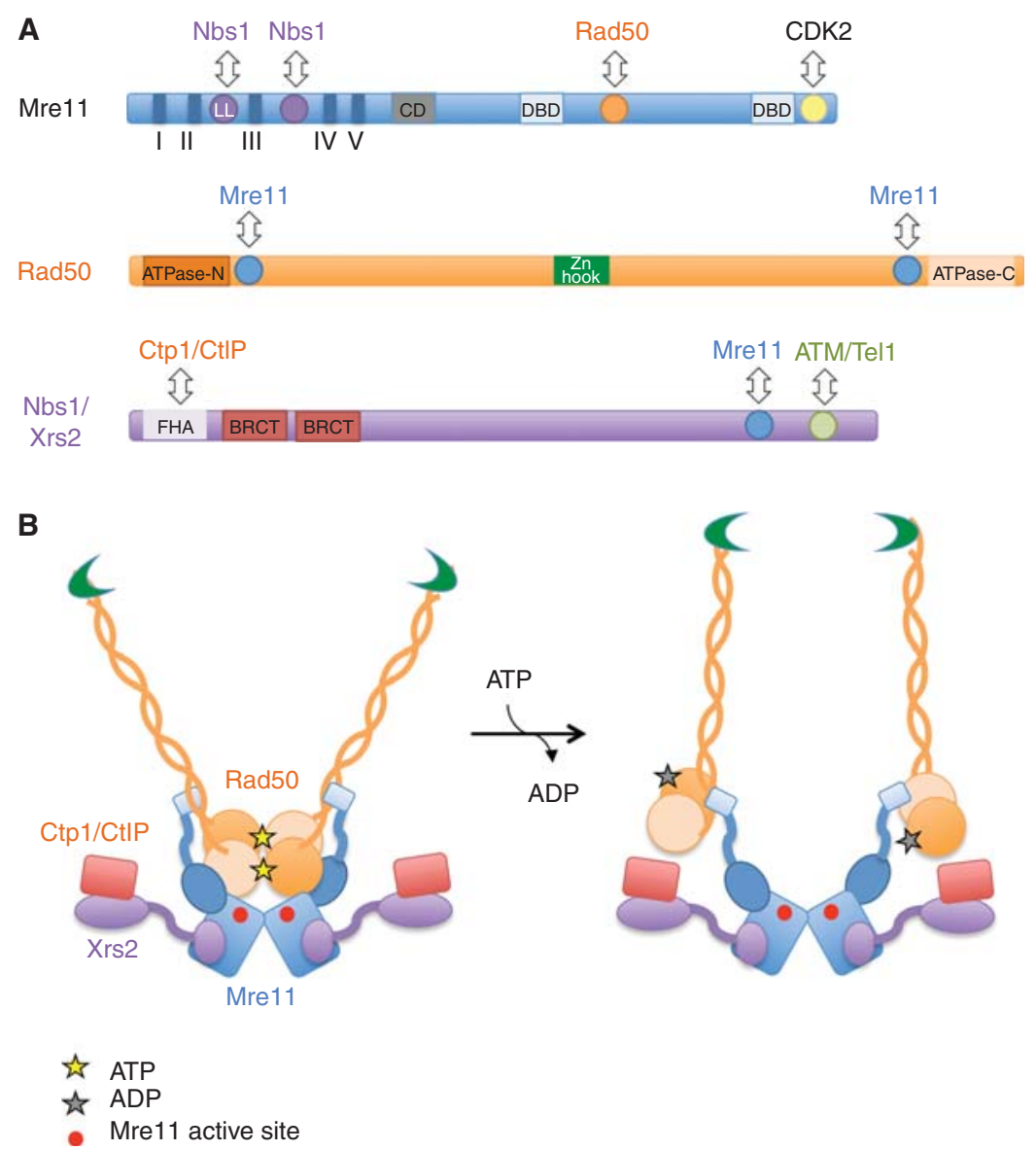

Figure 2. Structural organization of the MRX/N complex. (A) Schematic showing domains of the Mre11, Rad50, and Nbs1/Xrs2 proteins. Interaction domains are shown as color-coded circles, and other functional domains are indicated by rectangles. LL, latching loop; CD, capping domain; DBD, DNA-binding domain; FHA, forkhead associated; BRCT, BRCA1 carboxy-terminal domain. (B) Panel created from data in Lim et al. (2011) to show how ATP hydrolysis by Rad50 causes a conformational change exposing the Mre11 active site. Note that there are no structures of the entire MRX/N complex, or the complex with Sae2/Ctp1/CtIP, and the cartoon depicts the known interactions based on partial complexes.

vitro (Fig. 2A) (Bressan et al. 1998; Furuse et al. 1998; Usui et al. 1998; Moreau et al. 1999; Trujillo and Sung 2001). Substitution of conserved Asp or His residues within the nuclease motifs (e.g., D16, D56, H125, or H213 of ScMre11) with Asn or Ala abolishes exo- and endonuclease activities in vitro (Furuse et al. 1998; Usui et al. 1998; Moreau et al. 1999); hereafter, nucleasedeficient mre11 alleles are referred to as mre11$n d$. Mutation of His59 reduces the exonuclease activity to a greater extent than the endonuclease activity and has been used to evaluate the role of the exonuclease activity in vivo (Williams et al. 2008; Garcia et al. 2011). Two $\alpha$ helices of Mrel1 located carboxy terminal to the nuclease core domain are responsible for interaction with the Rad50 coiled-coil base (Lammens et al. 2011; Lim et al. 2011; Williams et al. 2011). Schizosaccharomyces pombe Mre11 interacts with Nbs1 via a eukaryotic-specific insertion between phosphoesterases motifs II and III, referred to as the latching loop, and through additional residues in the amino-terminal region (Schiller et al. 2012). Mutations within the latching loop 
L.S. Symington

that are found in individuals with ataxia-telangiectasia-like disorder (ATLD) or Nijmegen breakage syndrome (NBS)-like disorder disrupt the interaction with $\mathrm{Nbs} 1$. In the absence of Xrs2/Nbs1, or point mutations that abolish the interaction with $\mathrm{Nbs} 1, \mathrm{Mre} 11$ fails to localize to the nucleus. Interestingly, addition of an nuclear localization signal (NLS) to Mre11 can partially suppress the DNA damage sensitivity of the $x r s 2 \Delta$ mutant, indicating that one of the main functions for Xrs2 is Mre11 localization to the nucleus (Tsukamoto et al. 2005). The carboxyterminal 54 residues of murine Mre11 interact with cyclin-dependent kinase 2 (CDK2) to facilitate CtIP phosphorylation and stability (Buis et al. 2012).

Rad50 has a similar domain organization to the structural maintenance of chromosomes family of proteins, which are characterized by Walker A and B ATP-binding cassettes located at the amino- and carboxy-terminal regions of the primary sequence that come together by collapse of the intervening sequence to form a long antiparallel coiled-coil (Fig. 2) (Hopfner et al. 2000b). Two Rad50 ATP-binding cassettes interact with an Mre11 dimer to form a "head" domain with DNA-binding and ATP-regulated nuclease activity (Fig. 2B). The Rad50 coiled-coil domains emanate from the head and can interact with other MR complexes by $\mathrm{Zn}^{2+}$-mediated dimerization of the hook domains at the apexes of the coiled-coils intramolecularly, or intermolecularly to tether linear DNA molecules (Anderson et al. 2001; Chen et al. 2001; de Jager et al. 2001; Hopfner et al. 2002; Wiltzius et al. 2005). Mre11 stabilizes dimerization of Rad50 and stimulates Rad50 ATP hydrolysis. The ATPbound form of Rad50 negatively regulates the Mre11 nuclease activity by masking the active site of Mre11 (Lim et al. 2011). ATP hydrolysis triggers substantial conformational changes of both Rad50 and Mre11 within the MR complex, resulting in exposure of the Mre11 nuclease site and activation of DNA degradation (Lim et al. 2011; Mockel et al.2012). Mutation of conserved residues in the Walker A-type ATPase domain confer a rad50 null phenotype, whereas a class of mutations located close to the ATPase domain called rad50S behave similarly to mre11-nd al- leles (Alani et al. 1990). Exactly how the rad50S mutations affect the in vitro functions of the Mre11 complex has not been determined.

Although Mre11 and Rad50 are conserved in bacteria, bacteriophage T4, and archaea, Xrs2 and $\mathrm{Nbs} 1$ are unique to eukaryotes and are more diverged. The amino-terminal region of Xrs2/ Nbs1 has phosphoprotein-binding motifs that are separated from the Mre11 and Tel1/ATM interaction regions in the carboxyl terminus by a flexible linker (Lloyd et al. 2009; Williams et al. 2009). Xrs2 has only the conserved FHA domain, whereas Nbs1 has two BRCT domains adjacent to the FHA domain. Diphosphorylated pSDpTD motifs are Nbs1 FHA domain-binding targets and direct the interaction between Ctp1 (S. pombe Sae2 ortholog) and Nbs1; this interaction is important for resistance to IR and the topoisomerase I poison, camptothecin (CPT) in fission yeast (Lloyd et al. 2009; Williams et al. 2009). A conserved region within the carboxyterminal region of Xrs2/Nbs1 is responsible for Mre11 interaction (Tsukamoto et al. 2005).

\section{Sae2/Ctp1/CtIP}

Sae2 (also known as Com1) was originally identified by its requirement to process meiotic DSBs, and the phenotype conferred by sae $2 \Delta$ is very similar to mre11-nd and rad50S mutations (McKee and Kleckner 1997; Prinz et al. 1997; Mimitou and Symington 2009). Mammalian CtIP is thought to be the ortholog of Sae2, but sequence homology is limited to a small region of the carboxyl terminus that includes sites for cyclin-dependent kinase (CDK) and Mec1/ATR and Tel1/ATM phosphorylation, and an oligomerization motif $\left(\mathrm{LKEX}_{4}\right.$ $\mathrm{EV} / \mathrm{L}$ ) close to the amino terminus (Sartori et al. 2007; Kim et al. 2008; Wang et al. 2012). Although Sae2 does not form a stable complex with MRX in solution, together they form a higher-order complex in association with DNA (Lengsfeld et al. 2007). The similarity of the sae $2 \Delta$ and mre11-nd phenotypes initially led to speculation that Sae2 activates the Mre11 nuclease, and recombinant Sae2 does indeed stimulate the $3^{\prime}-5^{\prime}$ Mre11 exonuclease activity. In addition, Sae2 alone functions as an endonucle- 
Processing of DNA Breaks: Mechanism and Regulation

ase and cuts a variety of branched DNA structures with a preference for cleavage within an ssDNA region near a branch or hairpin-capped end, and the activity toward hairpin structures is stimulated by MRX (Lengsfeld et al. 2007).

\section{Exo1}

Exo1 is a member of the XPG family of nucleases, which includes Rad2/XPG, Rad27/FEN-1, and Yen1/GEN1 in eukaryotes (Szankasi and Smith 1995). These proteins have conserved nuclease motifs in the amino-terminal region but have distinct substrate preferences. Exol shows $5^{\prime}-3^{\prime}$ dsDNA exonuclease and $5^{\prime}$ flap endonuclease activities in vitro and is able to degrade from a dsDNA end or an internal nick releasing mononucleotide products (Szankasi and Smith 1992; Tran et al. 2004). Exo1 acts preferentially on dsDNA substrates with recessed $5^{\prime}$ ends, analogous to the ends produced by MRX and Sae2 in vivo (Cannavo et al. 2013). RPA stimulates Exo1 nucleolytic processing by binding to the ssDNA produced by end resection and preventing formation of nonproductive Exo1ssDNA complexes (Cannavo et al. 2013). MRX and Sae2 also stimulate Exo1-catalyzed degradation, which could occur by MRX-mediated unwinding of duplex ends to create the preferred substrate for Exo1 binding and flap endonuclease activity, or by clipping the $5^{\prime}$ strand to generate a recessed $5^{\prime}$ end for the exonuclease activity (Nicolette et al. 2010; Cannavo et al. 2013). Although no direct interaction between MRX or Sae2 and Exol has been reported, human CtIP and EXO1 do interact, and CtIP is required for recruitment of EXO1 to damaged sites in vivo (Eid et al. 2010). In yeast, MRX is required for Exo1 localization to DSBs, but Sae2 and Mre11 nuclease activity are not, suggesting the strand-separation function of MRX might be more important for recruitment than end clipping (Paull and Gellert 1999; Shim et al. 2010; Cannon et al. 2013). BLM is also able to stimulate EXO1 degradation by increasing the affinity of EXO1 for DNA ends, but this function is independent of the ATPase activity and is not conserved in yeast (Nimonkar et al. 2011; Cannavo et al. 2013).

\section{Sgs1/BLM-Dna2-RPA}

Sgs1, BLM, and WRN are members of the RecQ family of helicases that unwind DNA by ATP-dependent $3^{\prime}-5^{\prime}$ translocation on the $3^{\prime}$-terminated strand (Bernstein et al. 2010). Dna2, which is related to bacterial RecB proteins, shows helicase and ssDNA endonuclease activities in vitro (Bae et al. 1998; Budd et al. 2000). The nuclease activity of Dna2 is essential for end resection, but the helicase activity is dispensable, and Dna2 is dependent on Sgs1/BLM to generate the ssDNA substrate for degradation (Zhu et al. 2008; Cejka et al. 2010; Niu et al. 2010; Nimonkar et al. 2011). Sgs1-Dna2-catalyzed end resection is completely dependent on RPA (Cejka et al. 2010; Niu et al. 2010; Nimonkar et al. 2011; Chen et al. 2013). RPA directly interacts with Sgs1 and stimulates Sgs1 unwinding. The function of yRPA is only partially substituted by hRPA or E. coli SSB, suggesting a species-specific interaction is important and the role of RPA is not restricted to stabilizing the unwound strands. This is in contrast to the role of RPA in stimulation of Exol resection, which can be substituted by E. coli SSB (Cannavo et al. 2013). The Dna2 endonuclease can degrade either $3^{\prime}$ - or $5^{\prime}$-terminated ssDNA; however, in the presence of RPA, the $3^{\prime}$ nuclease activity is attenuated and the $5^{\prime}$ endonuclease activity is stimulated, explaining the strand bias of end resection (Cejka et al. 2010; Niu et al. 2010). Dna2 fails to localize to DSBs in the absence of RPA, which could account for the strict RPA requirement for Dna2-catalyzed resection in vivo (Chen et al. 2013).

Top3 and Rmi1, which function with Sgs1 to dissolve double Holliday intermediates (Bizard and Hickson 2014), stimulate end resection by increasing the affinity of Sgs1 for DNA ends (Cejka et al. 2010). Unlike dissolution, the role of Top3 in end resection is independent of its catalytic activity (Niu et al. 2010). Although Top3 and Rmil are not essential for Sgs1-Dna2RPA end resection in vitro, they are necessary in vivo (Zhu et al. 2008). Similarly, MRX stimulates end resection by Sgs1-Dna1-RPA by increasing Sgs1 helicase activity. The MRX stim- 
ulation can be bypassed by providing a dsDNA substrate with $5^{\prime}$ overhangs, suggesting MRX recruits Sgs 1 to DNA ends or creates an unwound end that is the preferred substrate for Sgs 1 binding (Niu et al. 2010). Sgs1 and Mre11 cofractionate after DNA damage, and MRX is required for Sgs1 and Dna2 recruitment to DSBs in vivo (Chiolo et al. 2005; Niu et al. 2010; Shim et al. 2010).

\section{Resection of Meiotic DSBs}

The Spo11 transesterase generates meiotic DSBs by forming a covalent linkage between a conserved tyrosine residue and the $5^{\prime}$ end of the cleaved strand (Keeney et al. 1997; Lam and Keeney 2014). A dimer of Spo11 acts to cut both DNA strands in concert. Spo11 is then removed endonucleolytically, releasing it with a short (12- to 40-nt) oligonucleotide attached (Neale et al. 2005). The sae $2 \Delta / \operatorname{ctp} 1 \Delta$, rad50S, and mre11-nd mutants of budding and fission yeast generate meiotic DSBs with Spol1 stably bound to the $5^{\prime}$ ends, suggesting the endonuclease activity of the MRX/N complex and/or Sae2/Ctp1 incises DNA internal to the DSB ends to liberate Spo11-oligonucleotides (Neale et al. 2005; Hartsuiker et al. 2009; Milman et al. 2009). Mutation of the Mre11 exonuclease activity (mre11-H59S) results in release of longer oligonucleotides attached to Spol1 (Garcia et al. 2011). In wild-type cells, the average length of $3^{\prime}$-ssDNA tails formed by end resection is $\sim 800 \mathrm{nt}$ but is reduced to $\sim 270 \mathrm{nt}$ in the exo1s mutant (Zakharyevich et al. 2010; Hodgson et al. 2011; Keelagher et al. 2011). These findings are consistent with a model whereby MRX and Sae2 incise the $5^{\prime}$ strand 250-300 nt from the Spo11-bound end and the Mre11 3'$5^{\prime}$ exonuclease degrades from the nick toward Spo11, whereas Exol degrades in the opposite direction, removing an additional $\sim 500 \mathrm{nt}$ (Fig. 3) (Zakharyevich et al. 2010; Garcia et al. 2011). DSB formation and processing are highly coordinated events during meiosis, and the intermediates with Spo11 attached to ends, or products of MRX-Sae2 processing are not observed in wild-type cells (Zakharyevich et al. 2010). STR-Dna2 does not contribute to resec- tion in meiosis, except in the absence of the Dmcl recombinase (Manfrini et al. 2010; Zakharyevich et al. 2010). Loss of Exol nuclease activity does not significantly impair meiotic recombination, indicating that the short ssDNA tails generated by MRX and Sae2 are sufficient for homologous pairing (Zakharyevich et al. 2010).

\section{Resection of Endonuclease-Generated DSBs}

$\mathrm{MRX} / \mathrm{N}$ rapidly localizes to DSBs and precedes recruitment of RPA and Rad51 (Nelms et al. 1998; Lisby et al. 2004). MRX localizes very close to a DSB and does not spread from the break site, consistent with a role in resection initiation but not in extensive resection (Shroff et al. 2004). In the absence of MRX, DSBs generated by the $\mathrm{HO}$ or I-SceI endonucleases remain stable for several hours (Ivanov et al. 1994; Tsubouchi and Ogawa 1998). Resection can be initiated by Exo1, but is inhibited by $\mathrm{Ku}$ binding to DNA ends; the absence of $\mathrm{Ku}$, or Exol overexpression, results in suppression of the mre $11 \Delta$ resection initiation defect (Bressan et al. 1999; Lee et al. 2002; Tomita et al. 2003; Williams et al. 2008; Mimitou and Symington 2010; Shim et al. 2010). STR-Dna2 is unable to initiate end resection without MRX, even in the absence of Ku (Mimitou and Symington 2010). Loss of the Mre11 nuclease activity or Sae2 results in a much shorter delay in resection initiation than observed in the absence of the MRX complex, attributed to the role of MRX in recruiting Exo1, Sgs1, and Dna2 to DSBs (Fig. 3) (Llorente and Symington 2004; Mimitou and Symington 2008; Shim et al. 2010). However, the Mre11 nuclease and Sae2 are essential for processing DSBs that have covalent adducts at the $5^{\prime}$ ends, such as Spol1-induced DSBs (see above) or hairpin-capped ends; these phenotypes are shared by rad50S mutants (Mimitou and Symington 2009). It is possible that the mechanism of end resection envisioned during meiosis occurs during DSB processing in mitotic cells, with Exo1 and Mre11 degrading bidirectionally from a nick created internal to the ends. Having Exo1 initiate resection from a nick 
A Covalent adduct or tightly bound protein STR-Dna2

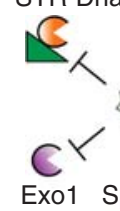

B "Clean" ends

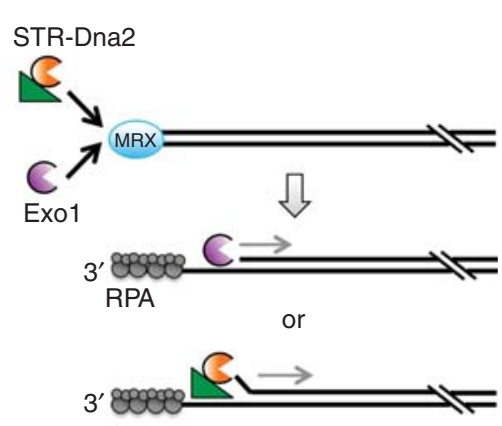

Figure 3. End processing in eukaryotes. $(A)$ Resection of meiotic DSBs involves MRX- and Sae2-dependent incision of the $5^{\prime}$ strand $\sim 270 \mathrm{nt}$ internal to the Spo11-bound end. MRX and Exo1 degrade bidirectionally from the nick to generate an ssDNA tail of $\sim 800 \mathrm{nt}$, and Spo11 is released from ends with a short (15- to 40-nt) oligonucleotide attached. The resulting ssDNA is bound by RPA, which is rapidly replaced by Rad51 and Dmc1 to promote strand invasion. In the absence of Dmc1, STR and Dna2 carry out more extensive end processing. This model could also apply to resection of DSBs blocked by a covalent adduct, or tightly bound protein such as $\mathrm{Ku}$, in vegetatively dividing cells. $(B)$ Resection of ends with no covalent modification (e.g., ends produced by the $\mathrm{HO}$ and I-SceI endonucleases) can initiate directly by STR-Dna2 or Exo1 via MRX recruitment. The two extensive resection mechanisms appear to function independently and redundantly at endonuclease-induced DSBs.

would overcome the problem of Ku inhibiting Exo1 at DNA ends.

In fission yeast and mammalian cells, the initial processing step by Mre11 nuclease and Sae2/Ctp1/CtIP appears to be more important for homology-dependent repair than in budding yeast (Limbo et al. 2007; Sartori et al. 2007; Buis et al. 2008; Langerak et al. 2011; Truong et al. 2013). The fission yeast ctp1s and mre11-H134S mutants show similar DNA damage sensitivity to the mre11 $1 \Delta$ mutant, and recruitment of RPA adjacent to an HOinduced DSB is greatly reduced (Limbo et al. 2007; Williams et al. 2008). Interestingly, null

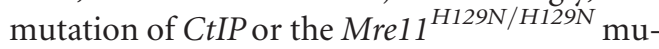
tation (nuclease defective) causes mouse embryonic lethality, highlighting the importance of MRN-CtIP regulated processing in mammalian cells (Chen et al. 2005; Buis et al. 2008). Knockdown of CtIP in human cells, or use of a conditional Mre $11^{H 129 N / H 129 N}$ cell line, results in a dramatic reduction in resection as determined by formation of IR-induced RPA or Rad51 foci (Sartori et al. 2007; Buis et al. 2008).

In the absence of Exol resection initiation occurs with normal kinetics, but resection 1$5 \mathrm{~kb}$ from the DSB is reduced (Llorente and Symington 2004; Mimitou and Symington 2008). DNA ends are stable for $\sim 6 \mathrm{~h}$ in the mre11 exo1s double mutant, but some end processing eventually occurs that must be caused by low residual STR-Dna2 activity (Tsubouchi and Ogawa 2000; Moreau et al. 2001). STR-Dna2 is mainly responsible for resection $>5 \mathrm{~kb}$ from DSB ends and acts redundantly with Exol in early resection (Gravel et al. 2008; Mimitou and Symington 2008; Zhu et al. 2008). The mrel1-nd sgs $1 \Delta$ double mutant shows synergistic sensitivity to IR and CPT, and delayed resection initiation as compared to the single mu- 
L.S. Symington

tants, suggesting STR-Dna2 is able to initiate end resection at clean ends in the absence of the Mre11 nuclease (Budd and Campbell 2009; Mimitou and Symington 2010; Shim et al. 2010). In the absence of Sgs1-Dna2 and Exo1, resection initiates by an endonucleolytic mechanism removing nucleotides from the $5^{\prime}$ end in increments of $\sim 100 \mathrm{nt}$; however, the length of ssDNA tails rarely exceeds $700 \mathrm{nt}$ (Gravel et al. 2008; Mimitou and Symington 2008; Zhu et al. 2008). Depletion of RPA from cells prevents extensive resection, similar to the phenotype of the exo1 $\Delta$ sgs $1 \Delta$ double mutant; furthermore, the $3^{\prime}$ tails formed by MRXSae 2 are unstable because of formation of secondary structures and degradation (Chen et al. 2013).

Cell Cycle, Ku, and DNA Damage Checkpoint Regulation of End Resection

HR is generally restricted to the $S$ and $G_{2}$ phases of the cell cycle, when a sister chromatid is available as a repair template. This restriction is mainly caused by reduced end resection in $\mathrm{G}_{1}$ compared with cycling or $\mathrm{G}_{2}$-arrested cells (Aylon et al. 2004; Ira et al. 2004; Jazayeri et al. 2006; Barlow et al. 2008; Zierhut and Diffley 2008). Indeed, restoration of end resection in $G_{1}$ permits $H R$ repair if a donor sequence is available (Zhang et al. 2009; Trovesi et al. 2011). Reduced resection in $G_{1}$ results from $\mathrm{Ku}$ binding to DNA ends, NHEJ, and low CDK (Cdc28) activity. Elimination of $\mathrm{Ku}$ or Dnl4 restores resection initiation to $G_{1}$-phase cells, but extensive resection is still partially defective (Clerici et al. 2008; Zierhut and Diffley 2008). Activation of Cdc28 in $\mathrm{G}_{1}$ restores resection, whereas inhibition of Cdc28 in $\mathrm{G}_{2}$ cells blocks resection (Aylon et al. 2004; Ira et al. 2004; Clerici et al. 2008).

Sae2 and Dna2 show S-phase-specific phosphorylation and are targets for Cdc28-mediated regulation of end resection (Baroni et al. 2004; Huertas et al. 2008; Chen et al. 2011). Mutation of Ser267 of Sae2 to a nonphosphorylatable residue, S267A, phenocopies sae2d, including hypersensitivity to camptothecin, defective sporulation, reduced hairpin-induced re- combination, impaired DSB processing, and delayed Rad52 recruitment (Huertas et al. 2008). Similarly, substitution of the equivalent CDK site in human CtIP (Thr847) to alanine impairs resection in human cells (Huertas and Jackson 2009). Cell-cycle regulation of S. pombe Ctp1 is mainly transcriptional (Limbo et al. 2007). Mutation of CDK consensus site residues in the amino-terminal region of Dna2 abolishes Cdc28-dependent phosphorylation (Chen et al. 2011). Substitution of Thr4, Ser17, and Ser327 with alanine (dna2-3A mutant) reduces extensive resection but not to the same extent as $d n a 2 \Delta$ or by inhibition of Cdc28. Dna2 has a bipartite nuclear localization sequence overlapping Ser17, and the dna2-S17A mutation reduces nuclear entry during $S$ phase and Dna2 localization to an HO-induced DSB (Kosugi et al. 2009; Chen et al. 2011); however, extensive resection is unaffected by the dna2-S17A mutant, suggesting the pool of nuclear Dna2 is sufficient for end processing. Expression of Dna2 with phosphomimetic substitutions of Thr4, Ser17, and Ser327 does not override Cdc28 regulation of extensive resection, indicating that there must be other Cdc2 8 targets.

The DNA damage sensitivity of the sae $2 \Delta /$ $c t p 1 \Delta$ mutant is suppressed by elimination of $\mathrm{Ku}$, and the suppression requires both Exo1 and Sgs1, suggesting CDK activation of Sae2 removes $\mathrm{Ku}$ from DNA ends to allow access to Exo1 or STR-Dna2 to DSBs (Fig. 3) (Limbo et al. 2007; Mimitou and Symington 2010; Langerak et al. 2011). It is possible that $\mathrm{Ku}$ is removed from ends by MRX-Sae2 clipping, similar to Spo11, or that a dynamic equilibrium exists between MRX-Sae2 and $\mathrm{Ku}$ binding, and that once MRX-Sae2 initiate resection, the preferred substrate for $\mathrm{Ku}$ binding is no longer available. Sae2 is still required for meiosis and hairpin cleavage in the absence of $\mathrm{Ku}$, indicating an essential role for Sae2 nuclease, or activation of the Mre11 endonuclease by Sae2, to process these ends (Rattray et al. 2005; Mimitou and Symington 2010). Interestingly, the meiotic defect of the Caenorhabditis elegans com-1 (Sae2/ CtIP ortholog) mutant is suppressed in the absence of $\mathrm{Ku}$, suggesting that Com $1 / \mathrm{Sae} 2$ may not play a direct role in the endonucleolytic re- 
Processing of DNA Breaks: Mechanism and Regulation

moval of Spo11 in all organisms (Lemmens et al. 2013).

Mec1/ATR and/or Tel1/ATM phosphorylate many of the proteins involved in end resection after DNA damage. Cell-cycle and DNA damage-dependent phosphorylation of Sae2 require $\mathrm{Mec} 1$ and Tel1, and mutations altering the main phosphorylation sites cause DNA damage sensitivity (Baroni et al. 2004). A highly conserved ATM/ATR site in the carboxy-terminal region of CtIP (Thr859 of hCtIP or Thr818 of XCtIP) is phosphorylated in response to DSBs and is required for CtIP association with chromatin, DNA end resection, and HR repair (Peterson et al. 2013; Wang et al. 2013).

Regulation of End Resection by Chromatin Binding and Remodeling Proteins

Rad9

Rad 9 is considered as an adaptor protein in the DNA damage checkpoint linking the upstream Mec1 kinase to the effector kinases, Rad53 and Chk1 (Harrison and Haber 2006). The Tudor domain of Rad 9 interacts with methylated K79 of histone $\mathrm{H} 3$, and the BRCT domain binds to $\mathrm{H} 2 \mathrm{~A}$ sites phosphorylated by $\mathrm{Mecl} / \mathrm{ATR}$ or Tel1/ATM following DNA damage $(\gamma \mathrm{H} 2 \mathrm{~A})$. In addition to its role in DNA damage checkpoint signaling, several studies have shown that Rad 9 prevents the accumulation of ssDNA at uncapped telomeres and slows resection of endonuclease-induced DSBs (Zubko et al. 2004; Lazzaro et al. 2008; Doksani and de Lange 2014). End resection is increased in the absence of Dot1 (encodes the methyltransferase for histone $\mathrm{H} 3 \mathrm{~K} 79$ ) and in the nonphosphorylatable $h 2 a$ S129A mutant, indicating that the end-protection function of Rad9 requires chromatin association (Lazzaro et al. 2008; Chen et al. 2012; Eapen et al. 2012). Resection of uncapped subtelomeric sequences is mostly Exo1-dependent in the presence or absence of Rad 9, with only a small contribution from the Sgs1 pathway (Ngo and Lydall 2010). However, the increased resection of sequences further from uncapped ends that is seen in the rad9s mutant is mainly caused by Sgs1 activity (Ngo and Lydall 2010).

\section{$53 B P 1$ and RIF1}

53BP1 ( p53 binding protein 1) shares a similar domain organization to Rad 9 and plays a comparable end-protection role at telomeres and DSBs. Like Rad9, 53BP1 binds chromatin constitutively through the Tudor domain and forms $\gamma$-H2AX-dependent foci in response to IR. Simultaneous loss of the mammalian telomerebinding complex, Shelterin, and 53BP1 causes extensive resection of telomeres, which is partially dependent on CtIP, BLM, and EXO1 (Sfeir and de Lange 2012). The association of 53BP1 with DSBs in $\mathrm{G}_{1}$ prevents ATM-dependent resection of AID- (activation-induced cytidine deaminase) or IR-induced DSBs. BRCA1 competes with 53BP1, binding to ends when cells are in the $S$ and $G_{2}$ phases of the cell cycle to promote end resection and homology-directed repair (Escribano-Diaz et al. 2013). Interestingly, the HR defect and chromosomal instability associated with loss of BRCA1 are abrogated in the absence of 53BP1 by restoration of CtIP and ATM-dependent end resection (Bouwman et al. 2010; Bunting et al. 2010). The role of 53BP1 in preventing end resection requires RIF1 (Chapman et al. 2013; Di Virgilio et al. 2013; Feng et al. 2013; Zimmermann et al. 2013). Rif1 was originally identified as a Rap1-interacting protein and modulates telomere length in budding yeast (Hardy et al. 1992). RIF1 has no obvious telomere function in mammals, but was shown to interact with the amino-terminal domain of 53BP1 (Silverman et al. 2004). Accumulation of RIF1 at DSBs is ATM- and 53BP1-dependent and requires ATM/ATR target sites (S/TQ) within the 53BP1 amino terminus.

\section{Chromatin-Remodeling Complexes}

How the resection machinery navigates nucleosomal DNA and nonhistone protein-DNA complexes is not well understood. Nucleosomes assembled on a linear dsDNA template impede resection by Exol in vitro, but the inhibitory effect is less for Sgs1-Dna2, particularly if a nucleosome-free gap is adjacent to the DNA ends (Adkins et al. 2013). ATP-dependent chromatin remodeling complexes translocate on dsDNA 
L.S. Symington

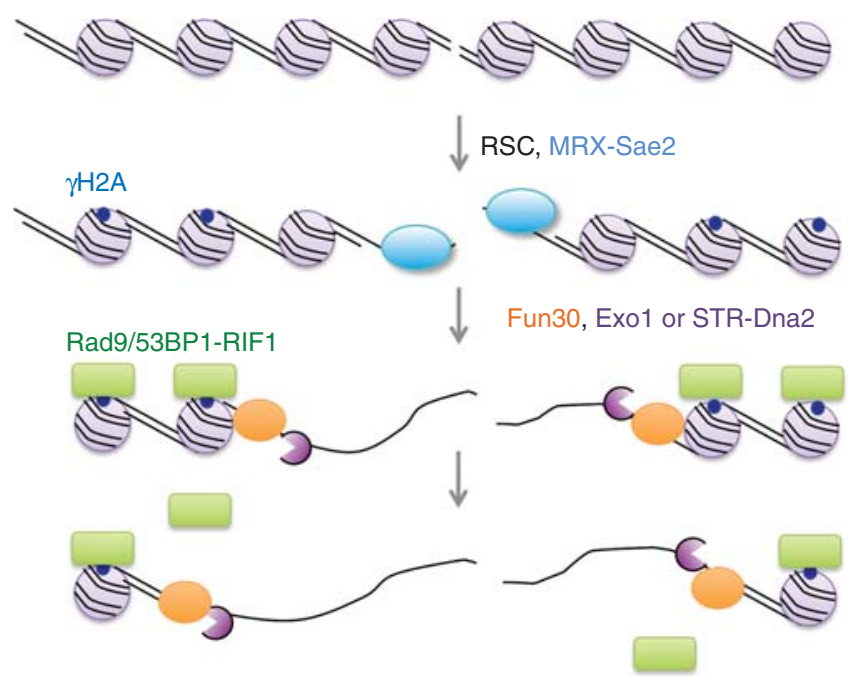

Figure 4. Chromatin and chromatin-bound proteins are barriers to end resection. The RSC complex is required for early end resection in collaboration with MRX, whereas more extensive end resection requires Fun30 acting with Exo1 and STR-Dna2. Chromatin-bound Rad 9 or 53BP1-RIF1 complexes impose an additional barrier that requires Fun30.

disrupting histone-DNA contacts by nucleosome sliding, eviction, or histone exchange. In budding yeast, the RSC, SWI/SNF, INO80, SWR-C, and Fun30 remodeling enzymes are all recruited to HO-induced DSBs (Bennett et al. 2013). The RSC complex is required for early resection and promotes recruitment of the MRX complex to DSBs, whereas Fun30 is important for extensive resection (Fig. 4) (Shim et al. 2007; Chen et al. 2012; Costelloe et al. 2012; Eapen et al. 2012). A role for the INO80 complex in early resection is only apparent in the absence of Fun30 and the RSC complex (Chen et al. 2012). Although Fun30 facilitates both extensive resection mechanisms, the phenotype of fun $30 \Delta$ is similar to exo $1 \Delta$ and overexpression of Exo1 suppresses the DNA damage sensitivity of the fun $30 \Delta$ mutant (Chen et al. 2012; Costelloe et al. 2012). Additionally, SMARCAD1, the human ortholog of Fun30, is required for RPA localization to laser-induced DNA damage, similar to the role of EXO1 (Costelloe et al. 2012; Tomimatsu et al. 2012). Although the recruitment of RSC, INO80, and Fun30 would be expected to precede resection, localization of these factors to DSBs is reduced in exo $1 \Delta$ sgs $1 \Delta$ cells; furthermore, recruitment of Sgs1, Dna2, and
Exol is reduced in the fun $30 \Delta$ mutant, indicating a complex interdependency. Interestingly, the extensive resection defect of the fun $30 \Delta \mathrm{mu}-$ tant is completely suppressed by elimination of Rad9, suggesting Fun30 helps to overcome the resection barrier formed by Rad9 (Chen et al. 2012; Eapen et al. 2012).

\section{CONCLUDING REMARKS}

Considerable progress has been made in identifying components of the end-resection machinery in eukaryotes, and the extensive resection pathways have been reconstituted in vitro. However, a detailed mechanistic understanding of resection initiation is lacking, in particular, how the Mre11 nuclease and Sae2/CtIP collaborate to initiate resection is poorly understood. NHEJ is a prominent repair pathway during the $G_{1}$ phase of the cell cycle in eukaryotes, and the initiation of end resection has emerged as a key regulatory step to differentiate between repair mechanisms. How the DNA damage checkpoint and CDKs coordinate to regulate resection, in particular in the chromatin context and during DNA replication, is an important issue for future studies. 


\section{ACKNOWLEDGMENTS}

Research in the Symington laboratory is supported by grants from the National Institutes of Health (R01 GM041784 and R01 GM094386).

\section{REFERENCES}

${ }^{*}$ Reference is also in this collection.

Adkins NL, Niu H, Sung P, Peterson CL. 2013. Nucleosome dynamics regulates DNA processing. Nat Struct Mol Biol 20: $836-842$.

Alani E, Padmore R, Kleckner N. 1990. Analysis of wild-type and rad50 mutants of yeast suggests an intimate relationship between meiotic chromosome synapsis and recombination. Cell 61: 419-436.

Anderson DG, Kowalczykowski SC. 1997a. The recombination hot spot Chi is a regulatory element that switches the polarity of DNA degradation by the RecBCD enzyme. Genes Dev 11: 571-581.

Anderson DG, Kowalczykowski SC. 1997b. The translocating RecBCD enzyme stimulates recombination by directing RecA protein onto ssDNA in a Chi-regulated manner. Cell 90: 77-86.

Anderson DE, Trujillo KM, Sung P, Erickson HP. 2001. Structure of the Rad50 x Mre11 DNA repair complex from Saccharomyces cerevisiae by electron microscopy. J Biol Chem 276: 37027-37033.

Aylon Y, Liefshitz B, Kupiec M. 2004. The CDK regulates repair of double-strand breaks by homologous recombination during the cell cycle. EMBO J 23: 4868-4875.

Bae SH, Choi E, Lee KH, Park JS, Lee SH, Seo YS. 1998. Dna2 of Saccharomyces cerevisiae possesses a singlestranded DNA-specific endonuclease activity that is able to act on double-stranded DNA in the presence of ATP. J Biol Chem 273: 26880-26890.

Barlow JH, Lisby M, Rothstein R. 2008. Differential regulation of the cellular response to DNA double-strand breaks in $\mathrm{G}_{1}$. Mol Cell 30: 73-85.

Baroni E, Viscardi V, Cartagena-Lirola H, Lucchini G, Longhese MP. 2004. The functions of budding yeast Sae2 in the DNA damage response require $\mathrm{Mecl}$ - and Tel1-dependent phosphorylation. Mol Cell Biol 24: 4151-4165.

Bennett G, Papamichos-Chronakis M, Peterson CL. 2013. DNA repair choice defines a common pathway for recruitment of chromatin regulators. Nat Commun 4: 2084.

Bernstein KA, Gangloff S, Rothstein R. 2010. The RecQ DNA helicases in DNA repair. Annu Rev Genet 44: 393-417.

* Bizard AH, Hickson ID. 2014. The dissolution of double Holliday junctions. Cold Spring Harb Perspect Biol doi: 10.1101/cshperspect.a016477.

Blackwood JK, Rzechorzek NJ, Abrams AS, Maman JD, Pellegrini L, Robinson NP. 2012. Structural and functiona insights into DNA-end processing by the archaeal HerA helicase-NurA nuclease complex. Nucl Acids Res 40: 3183-3196.

Blattner FR, Plunkett G III, Bloch CA, Perna NT, Burland V, Riley M, Collado-Vides J, Glasner JD, Rode CK, Mayhew
GF, et al. 1997. The complete genome sequence of Escherichia coli K-12. Science 277: 1453-1462.

Bouwman P, Aly A, Escandell JM, Pieterse M, Bartkova J, van der Gulden $H$, Hiddingh S, Thanasoula M, Kulkarni A, Yang Q, et al. 2010. 53BP1 loss rescues BRCA1 deficiency and is associated with triple-negative and BRCA-mutated breast cancers. Nat Struct Mol Biol 17: 688-695.

Bressan DA, Olivares HA, Nelms BE, Petrini JH. 1998. Alteration of N-terminal phosphoesterase signature motifs inactivates Saccharomyces cerevisiae Mre11. Genetics 150: 591-600.

Bressan DA, Baxter BK, Petrini JH. 1999. The Mre11-Rad50Xrs2 protein complex facilitates homologous recombination-based double-strand break repair in Saccharomyces cerevisiae. Mol Cell Biol 19: 7681-7687.

Budd ME, Campbell JL. 2009. Interplay of Mre11 nuclease with Dna2 plus Sgs1 in Rad51-dependent recombinational repair. PLoS ONE 4: e4267.

Budd ME, Choe W, Campbell JL. 2000. The nuclease activity of the yeast DNA2 protein, which is related to the RecBlike nucleases, is essential in vivo. J Biol Chem 275: 16518-16529.

Buis J, Wu Y, Deng Y, Leddon J, Westfield G, Eckersdorff M, Sekiguchi JM, Chang S, Ferguson DO. 2008. Mre11 nuclease activity has essential roles in DNA repair and genomic stability distinct from ATM activation. Cell 135: 85-96.

Buis J, Stoneham T, Spehalski E, Ferguson DO. 2012. Mre11 regulates CtIP-dependent double-strand break repair by interaction with CDK2. Nat Struct Mol Biol 19: 246252.

Bunting SF, Callen E, Wong N, Chen HT, Polato F, Gunn A, Bothmer A, Feldhahn N, Fernandez-Capetillo O, Cao L, et al. 2010. 53BP1 inhibits homologous recombination in Brcal-deficient cells by blocking resection of DNA breaks. Cell 141: 243-254.

Cannavo E, Cejka P, Kowalczykowski SC. 2013. Relationship of DNA degradation by Saccharomyces cerevisiae Exonuclease 1 and its stimulation by RPA and Mre11-Rad50Xrs2 to DNA end resection. Proc Natl Acad Sci 110: E1661-E1668.

Cannon B, Kuhnlein J, Yang SH, Cheng A, Schindler D, Stark JM, Russell R, Paull TT. 2013. Visualization of local DNA unwinding by Mre11/Rad50/Nbs1 using single-molecule FRET. Proc Natl Acad Sci 110: 1886818873.

Cejka P, Cannavo E, Polaczek P, Masuda-Sasa T, Pokharel S, Campbell JL, Kowalczykowski SC. 2010. DNA end resection by Dna2-Sgs1-RPA and its stimulation by Top3-Rmil and Mre11-Rad50-Xrs2. Nature 467: 112116.

Chapman JR, Barral P, Vannier JB, Borel V, Steger M, TomasLoba A, Sartori AA, Adams IR, Batista FD, Boulton SJ. 2013. RIF1 is essential for 53BP1-dependent nonhomologous end joining and suppression of DNA doublestrand break resection. Mol Cell 49: 858-871.

Chen L, Trujillo K, Ramos W, Sung P, Tomkinson AE. 2001. Promotion of Dnl4-catalyzed DNA end-joining by the Rad50/Mre11/Xrs2 and Hdf1/Hdf2 complexes. Mol Cell 8: 1105-1115. 
L.S. Symington

Chen PL, Liu F, Cai S, Lin X, Li A, Chen Y, Gu B, Lee EY Lee WH. 2005. Inactivation of CtIP leads to early embryonic lethality mediated by $\mathrm{G}_{1}$ restraint and to tumorigenesis by haploid insufficiency. Mol Cell Biol 25: 3535-3542.

Chen X, Niu H, Chung WH, Zhu Z, Papusha A, Shim EY, Lee SE, Sung P, Ira G. 2011. Cell cycle regulation of DNA double-strand break end resection by Cdk1-dependent Dna2 phosphorylation. Nat Struct Mol Biol 18: 10151019.

Chen X, Cui D, Papusha A, Zhang X, Chu CD, Tang J, Chen K, Pan X, Ira G. 2012. The Fun30 nucleosome remodeller promotes resection of DNA double-strand break ends. Nature 489: 576-580.

Chen H, Lisby M, Symington LS. 2013. RPA coordinates DNA end resection and prevents formation of DNA hairpins. Mol Cell 50: 589-600.

Chiolo I, Carotenuto W, Maffioletti G, Petrini JH, Foiani M, Liberi G. 2005. Srs2 and Sgs1 DNA helicases associate with Mre11 in different subcomplexes following checkpoint activation and CDK1-mediated Srs2 phosphorylation. Mol Cell Biol 25: 5738-5751.

Chung WH, Zhu Z, Papusha A, Malkova A, Ira G. 2010. Defective resection at DNA double-strand breaks leads to de novo telomere formation and enhances gene targeting. PLoS Genet 6: e1000948.

Churchill JJ, Anderson DG, Kowalczykowski SC. 1999 The RecBC enzyme loads RecA protein onto ssDNA asymmetrically and independently of chi, resulting in constitutive recombination activation. Genes Dev 13: 901-911.

Clerici M, Mantiero D, Guerini I, Lucchini G, Longhese MP. 2008. The Yku70-Yku80 complex contributes to regulate double-strand break processing and checkpoint activation during the cell cycle. EMBO Rep 9: 810-818.

Costelloe T, Louge R, Tomimatsu N, Mukherjee B, Martini E, Khadaroo B, Dubois K, Wiegant WW, Thierry A, Burma S, et al. 2012. The yeast Fun30 and human SMARCAD1 chromatin remodellers promote DNA end resection. Nature 489: 581-584.

de Jager M, van Noort J, van Gent DC, Dekker C, Kanaar R Wyman C. 2001. Human Rad50/Mre11 is a flexible complex that can tether DNA ends. Mol Cell 8: 11291135.

Dermic D. 2006. Functions of multiple exonucleases are essential for cell viability, DNA repair and homologous recombination in recD mutants of Escherichia coli. Genetics 172: 2057-2069.

Dillingham MS, Kowalczykowski SC. 2008. RecBCD enzyme and the repair of double-stranded DNA breaks. Microbiol Mol Biol Rev 72: 642-671.

Dillingham MS, Spies M, Kowalczykowski SC. 2003. RecBCD enzyme is a bipolar DNA helicase. Nature 423: 893-897.

Di Virgilio M, Callen E, Yamane A, Zhang W, Jankovic M, Gitlin AD, Feldhahn N, Resch W, Oliveira TY, Chait BT, et al. 2013. Rif1 prevents resection of DNA breaks and promotes immunoglobulin class switching. Science 339: $711-715$.

Dixon DA, Kowalczykowski SC. 1993. The recombination hotspot chi is a regulatory sequence that acts by attenu- ating the nuclease activity of the E. coli RecBCD enzyme. Cell 73: 87-96.

* Doksani Y, de Lange T. 2014. The role of DSB repair pathways at functional and dysfunctional telomeres. Cold Spring Harb Perspect Biol doi: 10.1101/cshperspect .a016576.

Eapen VV, Sugawara N, Tsabar M, Wu WH, Haber JE. 2012. The Saccharomyces cerevisiae chromatin remodeler Fun 30 regulates DNA end resection and checkpoint deactivation. Mol Cell Biol 32: 4727-4740.

Eid W, Steger M, El-Shemerly M, Ferretti LP, Pena-Diaz J, Konig C, Valtorta E, Sartori AA, Ferrari S. 2010. DNA end resection by CtIP and exonuclease 1 prevents genomic instability. EMBO Rep 11: 962-968.

Escribano-Diaz C, Orthwein A, Fradet-Turcotte A, Xing M, Young JT, Tkac J, Cook MA, Rosebrock AP, Munro M, Canny MD, et al. 2013. A cell cycle-dependent regulatory circuit composed of 53BP1-RIF1 and BRCA1-CtIP controls DNA repair pathway choice. Mol Cell 49: 872883.

Eykelenboom JK, Blackwood JK, Okely E, Leach DR. 2008. SbcCD causes a double-strand break at a DNA palindrome in the Escherichia coli chromosome. Mol Cell 29: 644-651.

Feng L, Fong KW, Wang J, Wang W, Chen J. 2013. RIF1 counteracts BRCA1-mediated end resection during DNA repair. J Biol Chem 288: 11135-11143.

Finkelstein IJ, Visnapuu ML, Greene EC. 2010. Single-molecule imaging reveals mechanisms of protein disruption by a DNA translocase. Nature 468: 983-987.

Fujikane R, Shinagawa H, Ishino Y. 2006. The archaeal Hjm helicase has recQ-like functions, and may be involved in repair of stalled replication fork. Genes Cells 11: 99-110.

Furuse M, Nagase Y, Tsubouchi H, Murakami-Murofushi K, Shibata T, Ohta K. 1998. Distinct roles of two separable in vitro activities of yeast Mre11 in mitotic and meiotic recombination. EMBO J 17: 6412-6425.

Garcia V, Phelps SE, Gray S, Neale MJ. 2011. Bidirectional resection of DNA double-strand breaks by Mre11 and Exo1. Nature 479: 241-244.

Gravel S, Chapman JR, Magill C, Jackson SP. 2008. DNA helicases Sgs1 and BLM promote DNA double-strand break resection. Genes Dev 22: 2767-2772.

Guy CP, Bolt EL. 2005. Archaeal Hel308 helicase targets replication forks in vivo and in vitro and unwinds lagging strands. Nucl Acids Res 33: 3678-3690.

Han ES, Cooper DL, Persky NS, Sutera VA Jr, Whitaker RD, Montello ML, Lovett ST. 2006. RecJ exonuclease: Substrates, products and interaction with SSB. Nucl Acids Res 34: 1084-1091.

Handa N, Morimatsu K, Lovett ST, Kowalczykowski SC. 2009. Reconstitution of initial steps of dsDNA break repair by the RecF pathway of E. coli. Genes Dev 23: 12341245.

Handa N, Yang L, Dillingham MS, Kobayashi I, Wigley DB, Kowalczykowski SC. 2012. Molecular determinants responsible for recognition of the single-stranded DNA regulatory sequence, chi, by RecBCD enzyme. Proc Natl Acad Sci 109: 8901-8906. 
Hardy CF, Sussel L, Shore D. 1992. A RAP1-interacting protein involved in transcriptional silencing and telomere length regulation. Genes Dev 6: 801-814.

Harrison JC, Haber JE. 2006. Surviving the breakup: The DNA damage checkpoint. Annu Rev Genet 40: 209235.

Hartsuiker E, Mizuno K, Molnar M, Kohli J, Ohta K, Carr AM. 2009. Ctp1/CtIP and Rad32/Mre11 nuclease activity are required for Rec12/Spo11 removal, but Rec12/ Spol1 removal is dispensable for other MRN-dependent meiotic functions. Mol Cell Biol 29: 1671-1681.

Hodgson A, Terentyev Y, Johnson RA, Bishop-Bailey A, Angevin T, Croucher A, Goldman AS. 2011. Mre11 and Exo1 contribute to the initiation and processivity of resection at meiotic double-strand breaks made independently of Spo11. DNA Repair (Amst) 10: 138-148.

Hopfner KP, Karcher A, Shin D, Fairley C, Tainer JA, Carney JP. 2000a. Mrel1 and Rad50 from Pyrococcus furiosus: Cloning and biochemical characterization reveal an evolutionarily conserved multiprotein machine. J Bacteriol 182: 6036-6041.

Hopfner KP, Karcher A, Shin DS, Craig L, Arthur LM, Carney JP, Tainer JA. 2000b. Structural biology of Rad50 ATPase: ATP-driven conformational control in DNA double-strand break repair and the ABC-ATPase superfamily. Cell 101: 789-800.

Hopfner KP, Craig L, Moncalian G, Zinkel RA, Usui T, Owen BA, Karcher A, Henderson B, Bodmer JL, McMurray CT, et al. 2002. The Rad50 zinc-hook is a structure joining Mre11 complexes in DNA recombination and repair. Nature 418: 562-566.

Hopkins BB, Paull TT. 2008. The P. furiosus mre11/rad50 complex promotes $5^{\prime}$ strand resection at a DNA doublestrand break. Cell 135: 250-260.

Huertas P, Jackson SP. 2009. Human CtIP mediates cell cycle control of DNA end resection and double strand break repair. J Biol Chem 284: 9558-9565.

Huertas P, Cortes-Ledesma F, Sartori AA, Aguilera A, Jackson SP. 2008. CDK targets Sae2 to control DNA-end resection and homologous recombination. Nature 455: 689-692.

Ira G, Pellicioli A, Balijja A, Wang X, Fiorani S, Carotenuto W, Liberi G, Bressan D, Wan L, Hollingsworth NM, et al. 2004. DNA end resection, homologous recombination and DNA damage checkpoint activation require CDK1. Nature 431: 1011-1017.

Ivanov EL, Sugawara N, White CI, Fabre F, Haber JE. 1994. Mutations in XRS2 and RAD50 delay but do not prevent mating-type switching in Saccharomyces cerevisiae. Mol Cell Biol 14: 3414-3425.

Jazayeri A, Falck J, Lukas C, Bartek J, Smith GC, Lukas J, Jackson SP. 2006. ATM- and cell cycle-dependent regulation of ATR in response to DNA double-strand breaks. Nat Cell Biol 8: 37-45.

Karanja KK, Cox SW, Duxin JP, Stewart SA, Campbell JL. 2012. DNA2 and EXO1 in replication-coupled, homology-directed repair and in the interplay between HDR and the FA/BRCA network. Cell Cycle 11: 3983-3996.

Keelagher RE, Cotton VE, Goldman AS, Borts RH. 2011. Separable roles for Exonuclease I in meiotic DNA doublestrand break repair. DNA Repair (Amst) 10: 126-137.
Keeney S, Giroux CN, Kleckner N. 1997. Meiosis-specific DNA double-strand breaks are catalyzed by Spo11, a member of a widely conserved protein family. Cell $\mathbf{8 8}$ : $375-384$.

Kim HS, Vijayakumar S, Reger M, Harrison JC, Haber JE, Weil C, Petrini JH. 2008. Functional interactions between Sae2 and the Mre11 complex. Genetics 178: 711-723.

Kosugi S, Hasebe M, Tomita M, Yanagawa H. 2009. Systematic identification of cell cycle-dependent yeast nucleocytoplasmic shuttling proteins by prediction of composite motifs. Proc Natl Acad Sci 106: 10171-10176.

* Lam I, Keeney S. 2015. Mechanism and regulation of meiotic recombination initiation. Cold Spring Harb Perspect Biol doi: 10.1101/cshperspect.a016634.

Lam ST, Stahl MM, McMilin KD, Stahl FW. 1974. Rec-mediated recombinational hot spot activity in bacteriophage $\lambda$ II. A mutation which causes hot spot activity. Genetics 77: 425-433.

Lammens K, Bemeleit DJ, Mockel C, Clausing E, Schele A, Hartung S, Schiller CB, Lucas M, Angermuller C, Soding J, et al. 2011. The Mre11:Rad50 structure shows an ATPdependent molecular clamp in DNA double-strand break repair. Cell 145: 54-66.

Langerak P, Mejia-Ramirez E, Limbo O, Russell P. 2011. Release of Ku and MRN from DNA ends by Mre11 nuclease activity and Ctp1 is required for homologous recombination repair of double-strand breaks. PLoS Genet 7: e1002271.

Lazzaro F, Sapountzi V, Granata M, Pellicioli A, Vaze M, Haber JE, Plevani P, Lydall D, Muzi-Falconi M. 2008. Histone methyltransferase Dot1 and Rad9 inhibit single-stranded DNA accumulation at DSBs and uncapped telomeres. EMBO J 27: 1502-1512.

Lee SE, Bressan DA, Petrini JH, Haber JE. 2002. Complementation between $\mathrm{N}$-terminal Saccharomyces cerevisiae mre11 alleles in DNA repair and telomere length maintenance. DNA Repair (Amst) 1: 27-40.

Lemmens BB, Johnson NM, Tijsterman M. 2013. COM-1 promotes homologous recombination during Caenorhabditis elegans meiosis by antagonizing Ku-mediated non-homologous end joining. PLoS Genet 9: e1003276.

Lengsfeld BM, Rattray AJ, Bhaskara V, Ghirlando R, Paull TT. 2007. Sae2 is an endonuclease that processes hairpin DNA cooperatively with the Mre11/Rad50/Xrs2 complex. Mol Cell 28: 638-651.

Lim HS, Kim JS, Park YB, Gwon GH, Cho Y. 2011. Crystal structure of the Mre11-Rad50-ATP $\gamma \mathrm{S}$ complex: Understanding the interplay between Mre11 and Rad50. Genes Dev 25: 1091-1104.

Limbo O, Chahwan C, Yamada Y, de Bruin RA, Wittenberg C, Russell P. 2007. Ctp1 is a cell-cycle-regulated protein that functions with Mre11 complex to control doublestrand break repair by homologous recombination. $\mathrm{Mol}$ Cell 28: 134-146.

Lisby M, Barlow JH, Burgess RC, Rothstein R. 2004. Choreography of the DNA damage response: Sspatiotemporal relationships among checkpoint and repair proteins. Cell 118: $699-713$.

Llorente B, Symington LS. 2004. The Mre11 nuclease is not required for $5^{\prime}$ to $3^{\prime}$ resection at multiple $\mathrm{HO}$-induced double-strand breaks. Mol Cell Biol 24: 9682-9694. 
L.S. Symington

Lloyd J, Chapman JR, Clapperton JA, Haire LF, Hartsuiker E, Li J, Carr AM, Jackson SP, Smerdon SJ. 2009. A supramodular FHA/BRCT-repeat architecture mediates Nbsl adaptor function in response to DNA damage. Cell 139: 100-111.

Lobachev KS, Gordenin DA, Resnick MA. 2002. The Mre11 complex is required for repair of hairpin-capped doublestrand breaks and prevention of chromosome rearrangements. Cell 108: 183-193.

Lovett ST, Kolodner RD. 1989. Identification and purification of a single-stranded-DNA-specific exonuclease encoded by the recJ gene of Escherichia coli. Proc Natl Acad Sci 86: 2627-2631.

Lovett ST, Luisi-DeLuca C, Kolodner RD. 1988. The genetic dependence of recombination in recD mutants of Escherichia coli. Genetics 120: $37-45$.

Manfrini N, Guerini I, Citterio A, Lucchini G, Longhese MP. 2010. Processing of meiotic DNA double strand breaks requires cyclin-dependent kinase and multiple nucleases. J Biol Chem 285: 11628-11637.

McKee AH, Kleckner N. 1997. A general method for identifying recessive diploid-specific mutations in Saccharomyces cerevisiae, its application to the isolation of mutants blocked at intermediate stages of meiotic prophase and characterization of a new gene SAE2. Genetics 146: 797-816.

* Mehta A, Haber JE. 2014. Sources of DNA double-strand breaks and models for recombinational DNA repair. Cold Spring Harb Perspect Biol doi: 10.1101/cshperspect. a016428.

Milman N, Higuchi E, Smith GR. 2009. Meiotic DNA double-strand break repair requires two nucleases, MRN and Ctp1, to produce a single size class of Rec12 (Spo11)oligonucleotide complexes. Mol Cell Biol 29: 5998-6005.

Mimitou EP, Symington LS. 2008. Sae2, Exo1 and Sgs1 collaborate in DNA double-strand break processing. Nature 455: $770-774$.

Mimitou EP, Symington LS. 2009. DNA end resection: Many nucleases make light work. DNA Repair (Amst) 8: 983-995.

Mimitou EP, Symington LS. 2010. Ku prevents Exo1 and Sgs1-dependent resection of DNA ends in the absence of a functional MRX complex or Sae2. EMBO J 29: 3358 3369.

Mockel C, Lammens K, Schele A, Hopfner KP. 2012. ATP driven structural changes of the bacterial Mre11:Rad50 catalytic head complex. Nucl Acids Res 40: 914-927.

Moreau S, Ferguson JR, Symington LS. 1999. The nuclease activity of Mrel1 is required for meiosis but not for mating type switching, end joining, or telomere maintenance. Mol Cell Biol 19: 556-566.

Moreau S, Morgan EA, Symington LS. 2001. Overlapping functions of the Saccharomyces cerevisiae Mre11, Exo1 and Rad27 nucleases in DNA metabolism. Genetics 159: 1423-1433.

Neale MJ, Pan J, Keeney S. 2005. Endonucleolytic processing of covalent protein-linked DNA double-strand breaks. Nature 436: 1053-1057.

Nelms BE, Maser RS, MacKay JF, Lagally MG, Petrini JH. 1998. In situ visualization of DNA double-strand break repair in human fibroblasts. Science 280: 590-592.
Ngo HP, Lydall D. 2010. Survival and growth of yeast without telomere capping by Cdc13 in the absence of Sgs1, Exo1, and Rad9. PLoS Genet 6: e1001072.

Nicolette ML, Lee K, Guo Z, Rani M, Chow JM, Lee SE, Paull TT. 2010. Mre11-Rad50-Xrs2 and Sae2 promote $5^{\prime}$ strand resection of DNA double-strand breaks. Nat Struct Mol Biol 17: 1478-1485.

Nimonkar AV, Genschel J, Kinoshita E, Polaczek P, Campbell JL, Wyman C, Modrich P, Kowalczykowski SC. 2011. BLM-DNA2-RPA-MRN and EXO1-BLM-RPA-MRN constitute two DNA end resection machineries for human DNA break repair. Genes Dev 25: 350-362.

Niu H, Chung WH, Zhu Z, Kwon Y, Zhao W, Chi P, Prakash R, Seong C, Liu D, Lu L, et al. 2010. Mechanism of the ATP-dependent DNA end-resection machinery from Saccharomyces cerevisiae. Nature 467: 108-111.

Oyama T, Oka H, Mayanagi K, Shirai T, Matoba K, Fujikane R, Ishino Y, Morikawa K. 2009. Atomic structures and functional implications of the archaeal RecQ-like helicase Hjm. BMC Struct Biol 9: 2.

Paull TT, Gellert M. 1999. Nbs1 potentiates ATP-driven DNA unwinding and endonuclease cleavage by the Mre11/Rad50 complex. Genes Dev 13: 1276-1288.

Persky NS, Lovett ST. 2008. Mechanisms of recombination: Lessons from E. coli. Crit Rev Biochem Mol Biol 43: 347370.

Peterson SE, Li Y, Chait BT, Gottesman ME, Baer R, Gautier J. 2011. Cdk1 uncouples CtIP-dependent resection and Rad51 filament formation during M-phase doublestrand break repair. J Cell Biol 194: 705-720.

Peterson SE, Li Y, Wu-Baer F, Chait BT, Baer R, Yan H, Gottesman ME, Gautier J. 2013. Activation of DSB processing requires phosphorylation of CtIP by ATR. Mol Cell 49: 657-667.

Prinz S, Amon A, Klein F. 1997. Isolation of COM1, a new gene required to complete meiotic double-strand breakinduced recombination in Saccharomyces cerevisiae. Genetics 146: 781-795.

Rattray AJ, Shafer BK, Neelam B, Strathern JN. 2005. A mechanism of palindromic gene amplification in Saccharomyces cerevisiae. Genes Dev 19: 1390-1399.

Sartori AA, Lukas C, Coates J, Mistrik M, Fu S, Bartek J, Baer R, Lukas J, Jackson SP. 2007. Human CtIP promotes DNA end resection. Nature 450: 509-514.

Schiller CB, Lammens K, Guerini I, Coordes B, Feldmann H, Schlauderer F, Mockel C, Schele A, Strasser K, Jackson SP, et al. 2012. Structure of Mre11-Nbs1 complex yields insights into ataxia-telangiectasia-like disease mutations and DNA damage signaling. Nat Struct Mol Biol 19: 693-700.

Sfeir A, de Lange T. 2012. Removal of shelterin reveals the telomere end-protection problem. Science 336: 593-597.

Shim EY, Hong SJ, Oum JH, Yanez Y, Zhang Y, Lee SE. 2007. RSC mobilizes nucleosomes to improve accessibility of repair machinery to the damaged chromatin. Mol Cell Biol 27: 1602-1613.

Shim EY, Chung WH, Nicolette ML, Zhang Y, Davis M, Zhu Z, Paull TT, Ira G, Lee SE. 2010. Saccharomyces cerevisiae Mre11/Rad50/Xrs2 and Ku proteins regulate association 
of Exo1 and Dna2 with DNA breaks. EMBO J 29: $3370-$ 3380.

Shroff R, Arbel-Eden A, Pilch D, Ira G, Bonner WM, Petrini JH, Haber JE, Lichten M. 2004. Distribution and dynamics of chromatin modification induced by a defined DNA double-strand break. Curr Biol 14: 17031711.

Silverman J, Takai H, Buonomo SB, Eisenhaber F, de Lange T. 2004. Human Rif1, ortholog of a yeast telomeric protein, is regulated by ATM and 53BP1 and functions in the S-phase checkpoint. Genes Dev 18: 2108-2119.

Singleton MR, Dillingham MS, Gaudier M, Kowalczykowski SC, Wigley DB. 2004. Crystal structure of RecBCD enzyme reveals a machine for processing DNA breaks. $\mathrm{Na}$ ture 432: 187-193.

Smith GR. 2001. Homologous recombination near and far from DNA breaks: Alternative roles and contrasting views. Annu Rev Genet 35: 243-274.

Spies M, Bianco PR, Dillingham MS, Handa N, Baskin RJ, Kowalczykowski SC. 2003. A molecular throttle: The recombination hotspot chi controls DNA translocation by the RecBCD helicase. Cell 114: 647-654.

* Syeda AH, Hawkins M, McGlynn P. 2014. Recombination and replication. Cold Spring Harb Perspect Biol doi: 10.1101/cshperspect.a016550.

Szankasi P, Smith GR. 1992. A DNA exonuclease induced during meiosis of Schizosaccharomyces pombe. J Biol Chem 267: 3014-3023.

Szankasi P, Smith GR. 1995. A role for exonuclease I from S. pombe in mutation avoidance and mismatch correction. Science 267: 1166-1169.

Taylor AF, Smith GR. 1985. Substrate specificity of the DNA unwinding activity of the RecBC enzyme of Escherichia coli. J Mol Biol 185: 431-443.

Taylor AF, Smith GR. 2003. RecBCD enzyme is a DNA helicase with fast and slow motors of opposite polarity. Nature 423: 889-893.

Thaler DS, Sampson E, Siddiqi I, Rosenberg SM, Thomason LC, Stahl FW, Stahl MM. 1989. Recombination of bacteriophage $\lambda$ in recD mutants of Escherichia coli. Genome 31: $53-67$.

Tomimatsu N, Mukherjee B, Deland K, Kurimasa A, Bolderson E, Khanna KK, Burma S. 2012. Exo1 plays a major role in DNA end resection in humans and influences double-strand break repair and damage signaling decisions. DNA Repair (Amst) 11: 441-448.

Tomita K, Matsuura A, Caspari T, Carr AM, Akamatsu Y, Iwasaki H, Mizuno K, Ohta K, Uritani M, Ushimaru T, et al. 2003. Competition between the Rad50 complex and the Ku heterodimer reveals a role for Exol in processing double-strand breaks but not telomeres. Mol Cell Biol 23: 5186-5197.

Tran PT, Erdeniz N, Symington LS, Liskay RM. 2004. EXO1-A multi-tasking eukaryotic nuclease. DNA Repair (Amst) 3: 1549-1559.

Trovesi C, Falcettoni M, Lucchini G, Clerici M, Longhese MP. 2011. Distinct Cdk1 requirements during singlestrand annealing, noncrossover, and crossover recombination. PLoS Genet 7: e1002263.
Trujillo KM, Sung P. 2001. DNA structure-specific nuclease activities in the Saccharomyces cerevisiae Rad50* Mre11 complex. J Biol Chem 276: 35458-35464.

Trujillo KM, Yuan SS, Lee EY, Sung P. 1998. Nuclease activities in a complex of human recombination and DNA repair factors Rad50, Mre11, and p95. J Biol Chem 273: 21447-21450.

Truong LN, Li Y, Shi LZ, Hwang PY, He J, Wang H, Razavian N, Berns MW, Wu X. 2013. Microhomology-mediated end joining and homologous recombination share the initial end resection step to repair DNA double-strand breaks in mammalian cells. Proc Natl Acad Sci 110: 77207725 .

Tsubouchi H, Ogawa H. 1998. A novel mre11 mutation impairs processing of double-strand breaks of DNA during both mitosis and meiosis. Mol Cell Biol 18: 260268.

Tsubouchi H, Ogawa H. 2000. Exo1 roles for repair of DNA double-strand breaks and meiotic crossing over in Saccharomyces cerevisiae. Mol Biol Cell 11: 2221-2233.

Tsukamoto Y, Mitsuoka C, Terasawa M, Ogawa H, Ogawa T. 2005. Xrs2p regulates Mre11p translocation to the nucleus and plays a role in telomere elongation and meiotic recombination. Mol Biol Cell 16: 597-608.

Usui T, Ohta T, Oshiumi H, Tomizawa J, Ogawa H, Ogawa T. 1998. Complex formation and functional versatility of Mre11 of budding yeast in recombination. Cell 95: 705716.

Wang J, Chen R, Julin DA. 2000. A single nuclease active site of the Escherichia coli RecBCD enzyme catalyzes singlestranded DNA degradation in both directions. J Biol Chem 275: 507-513.

Wang H, Shao Z, Shi LZ, Hwang PY, Truong LN, Berns MW, Chen DJ, Wu X. 2012. CtIP protein dimerization is critical for its recruitment to chromosomal DNA doublestranded breaks. J Biol Chem 287: 21471-21480.

Wang H, Shi LZ, Wong CC, Han X, Hwang PY, Truong LN, Zhu Q, Shao Z, Chen DJ, Berns MW, et al. 2013. The interaction of CtIP and Nbs1 connects CDK and ATM to regulate HR-mediated double-strand break repair. PLoS Genet 9: e1003277.

Williams RS, Moncalian G, Williams JS, Yamada Y, Limbo O, Shin DS, Groocock LM, Cahill D, Hitomi C, Guenther G, et al. 2008. Mre11 dimers coordinate DNA end bridging and nuclease processing in double-strand-break repair. Cell 135: 97-109.

Williams RS, Dodson GE, Limbo O, Yamada Y, Williams JS, Guenther G, Classen S, Glover JN, Iwasaki H, Russell P, et al. 2009. Nbs1 flexibly tethers Ctp1 and Mre11-Rad50 to coordinate DNA double-strand break processing and repair. Cell 139: 87-99.

Williams GJ, Williams RS, Williams JS, Moncalian G, Arvai AS, Limbo O, Guenther G, Sildas S, Hammel M, Russell P, et al. 2011. ABC ATPase signature helices in Rad50 link nucleotide state to Mre11 interface for DNA repair. Nat Struct Mol Biol 18: 423-431.

Wiltzius JJ, Hohl M, Fleming JC, Petrini JH. 2005. The Rad50 hook domain is a critical determinant of Mre11 complex functions. Nat Struct Mol Biol 12: 403-407.

* Wyatt HDM, West SC. 2014. Holliday junction resolvases. Cold Spring Harb Perspect Biol doi: 10.1101/cshper spect.a016485. 


\section{L.S. Symington}

Yang L, Handa N, Liu B, Dillingham MS, Wigley DB, Kowalczykowski SC. 2012. Alteration of chi recognition by RecBCD reveals a regulated molecular latch and suggests a channel-bypass mechanism for biological control. Proc Natl Acad Sci 109: 8907-8912.

Zakharyevich K, Ma Y, Tang S, Hwang PY, Boiteux S, Hunter N. 2010. Temporally and biochemically distinct activities of Exol during meiosis: Double-strand break resection and resolution of double Holliday junctions. Mol Cell 40: $1001-1015$.

Zhang Y, Shim EY, Davis M, Lee SE. 2009. Regulation of repair choice: Cdk1 suppresses recruitment of end joining factors at DNA breaks. DNA Repair (Amst) 8: 12351241.
Zhu Z, Chung WH, Shim EY, Lee SE, Ira G. 2008. Sgs1 helicase and two nucleases Dna2 and Exo1 resect DNA double-strand break ends. Cell 134: 981-994.

Zierhut C, Diffley JF. 2008. Break dosage, cell cycle stage and DNA replication influence DNA double strand break response. EMBO J 27: 1875-1885.

Zimmermann M, Lottersberger F, Buonomo SB, Sfeir A, de Lange T. 2013. 53BP1 regulates DSB repair using Rif1 to control 5' end resection. Science 339: 700-704.

Zubko MK, Guillard S, Lydall D. 2004. Exo1 and Rad24 differentially regulate generation of ssDNA at telomeres of Saccharomyces cerevisiae cdc13-1 mutants. Genetics 168: 103-115. 


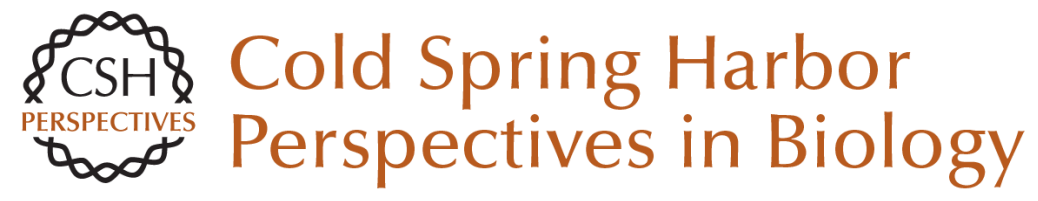

\section{End Resection at Double-Strand Breaks: Mechanism and Regulation}

Lorraine S. Symington

Cold Spring Harb Perspect Biol 2014; doi: 10.1101/cshperspect.a016436

Subject Collection DNA Recombination

Meiotic Recombination: The Essence of Heredity Neil Hunter

Regulation of Recombination and Genomic Maintenance Wolf-Dietrich Heyer

Initiation of Meiotic Homologous Recombination: Flexibility, Impact of Histone Modifications, and Chromatin Remodeling Lóránt Székvölgyi, Kunihiro Ohta and Alain Nicolas

Mechanism and Regulation of Meiotic

Recombination Initiation Isabel Lam and Scott Keeney

Homologous Recombination and Human Health: The Roles of BRCA1, BRCA2, and Associated Proteins

Rohit Prakash, Yu Zhang, Weiran Feng, et al.

\section{Cell Biology of Mitotic Recombination}

Michael Lisby and Rodney Rothstein

DNA-Pairing and Annealing Processes in

Homologous Recombination and

Homology-Directed Repair

Scott W. Morrical

Mediators of Homologous DNA Pairing

Alex Zelensky, Roland Kanaar and Claire Wyman
An Overview of the Molecular Mechanisms of

Recombinational DNA Repair

Stephen C. Kowalczykowski

Recombination, Pairing, and Synapsis of Homologs during Meiosis

Denise Zickler and Nancy Kleckner

DNA Strand Exchange and RecA Homologs in Meiosis

M. Scott Brown and Douglas K. Bishop

Meiosis and Maternal Aging: Insights from

Aneuploid Oocytes and Trisomy Births Mary Herbert, Dimitrios Kalleas, Daniel Cooney, et al.

Mismatch Repair during Homologous and Homeologous Recombination Maria Spies and Richard Fishel

Mechanisms of Gene Duplication and Amplification Andrew B. Reams and John R. Roth

The Role of Double-Strand Break Repair Pathways at Functional and Dysfunctional Telomeres Ylli Doksani and Titia de Lange

Regulation of DNA Pairing in Homologous Recombination James M. Daley, William A. Gaines, YoungHo Kwon, et al.

For additional articles in this collection, see http://cshperspectives.cshlp.org/cgi/collection/

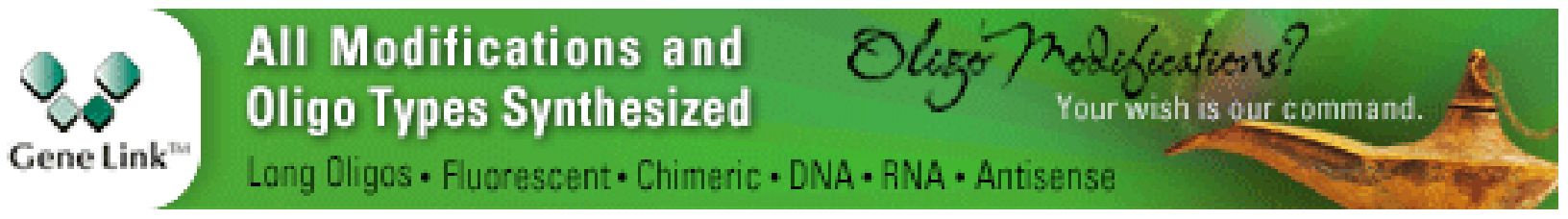


For additional articles in this collection, see http://cshperspectives.cshlp.org/cgi/collection/

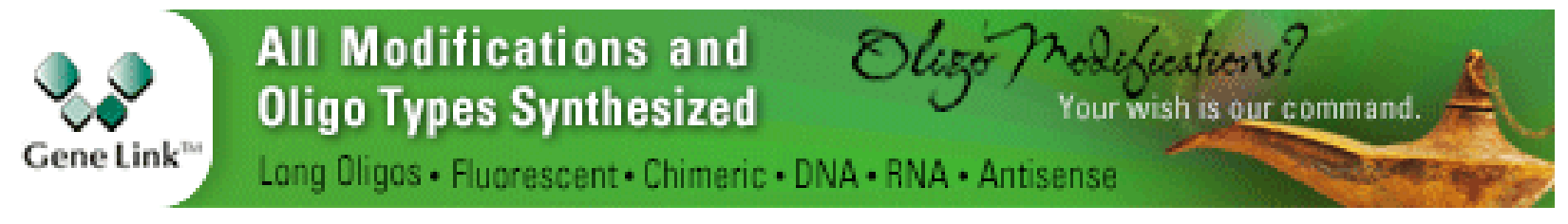

Copyright @ 2014 Cold Spring Harbor Laboratory Press; all rights reserved 